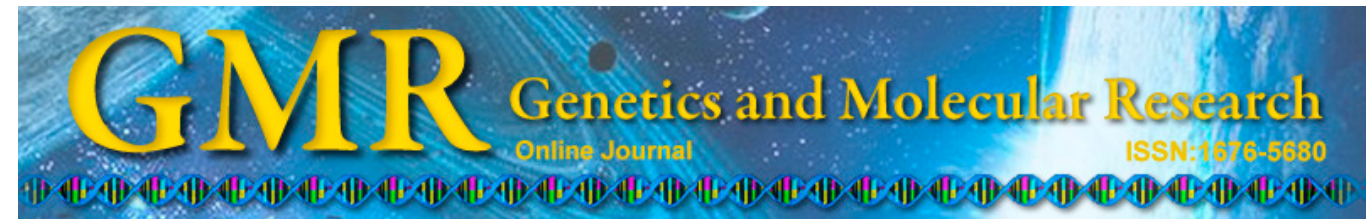

\title{
Molecular and morphological characterization of local apple cultivars in Southern Spain
}

\author{
L.F. Pérez-Romero ${ }^{1}$, M.P. Suárez ${ }^{2}$, E. Dapena ${ }^{3}$ and P. Rallo ${ }^{2}$ \\ ${ }^{1}$ Instituto de Investigación y Formación Agraria y Pesquera, \\ Centro "Las Torres-Tomejil”, Alcalá del Río, Sevilla, Spain \\ ${ }^{2}$ Departamento de Ciencias Agroforestales, Universidad de Sevilla, \\ Sevilla, Spain \\ ${ }^{3}$ Servicio Regional de Investigación y Desarollo Agroalimentario, \\ Villaviciosa, Asturias, Spain \\ Corresponding author: P. Rallo \\ E-mail: prallo@us.es
}

Genet. Mol. Res. 14 (1): 1487-1501 (2015)

Received April 24, 2014

Accepted October 9, 2014

Published February 20, 2015

DOI http://dx.doi.org/10.4238/2015.February.20.4

\begin{abstract}
The number of local and traditional fruit cultivars in Andalusia (Southern Spain) has decreased dramatically since the 1970s when new commercial cultivars from breeding programs were introduced, replacing old varieties, and thus decreasing genetic diversity. The present study was included in a genetic resources project with the objective of identifying and preserving traditional fruit tree cultivars in Southern Spain. The goal of this study was to begin the characterization of 29 apple accessions (Malus x domestica Borkh) belonging to 13 traditional cultivar denominations. For molecular characterization studies, 12 simple sequence repeat markers previously developed for apple species were used. Morphological characterization was performed using 33 fruit traits. A total of 115 alleles were amplified for the 12 loci, ranging from 7 (CH01h01, CH01h10, and GD 12) to 13 alleles per locus ( $\mathrm{CH} 02 \mathrm{c} 11)$. Forty-one alleles were unique to specific genotypes. The locus with the highest number of detected unique alleles was $\mathrm{CH} 01 \mathrm{f0} b \mathrm{~b}$ with 6 alleles. Expected heterozygosity
\end{abstract}


ranged from 0.74 for $\mathrm{CH} 01 \mathrm{~h} 10$ to 0.88 for $\mathrm{CH} 02 \mathrm{c} 11$, with an average of 0.82 . Observed heterozygosity varied from 0.45 for $\mathrm{CH} 01 \mathrm{~h} 01$ to 1.0 for $\mathrm{CH} 02 \mathrm{~d} 08$, with an average of 0.86 . Three homonyms were found for accessions belonging to varieties 'Maguillo', 'Pero Minguela', and 'Castellana'. The most discriminant morphological characters studied revealed no homonyms or synonyms among cultivar denominations, although they are useful for describing varietal characteristics that have not been previously defined.

Key words: Andalusia region; Genetic resources; Local varieties; Malus x domestica Borkh; Simple-sequence repeat

\section{INTRODUCTION}

Apple (Malus $\mathrm{x}$ domestica Borkh.) is the fourth most important fruit tree crop in the world, and the sixth most important in Spain. Most varieties grown in Spanish orchards originated in foreign countries (Pereira-Lorenzo et al., 2008). However, in some areas of Northern Spain, a large number of traditional Spanish varieties can be found, most of which are conserved in several national germplasm banks (Pereira-Lorenzo et al., 2007; Urrestarazu et al., 2012).

The Andalusian region in southern Spain is an important area for plant genetic diversity. A high number of fruit landraces were traditionally cultivated in small private orchards in different areas because these landraces are well-adapted to the soil and climatic conditions of this region. Apple species are grown in very few areas of Andalusia and thus there is a smaller number of traditional apple cultivars compared to Northern Spain. However, none of these cultivars are currently preserved in any of the Spanish germplasm banks and are in danger of disappearing.

The collection, characterization, conservation, and sustainable use of food genetic resources have become a primary goal of international institutions. A genetic plant resources survey was carried out by the University of Seville over 3 years (2007-2010) to preserve traditional fruit cultivars in Andalusia. A large number of old traditional cultivars from different fruit species was identified in the survey, including 13 apple varieties.

Good primary characterization and discrimination of local varieties has become an essential goal in plant genetic resources management as different varieties with the same name (known as homonyms) are frequently found in traditional plant germplasms, and in some cases the same variety receives different names (known as synonyms) (Hend et al., 2009; Rao et al., 2010).

Although morphological traits have been widely used to discriminate between varieties of the same species (Cantini et al., 1999; Barranco and Rallo, 2000), these characteristics are affected by environmental conditions such as rainfall or solar radiation (Rotondi et al., 2003). DNA markers have been developed and are currently used for germplasm genotyping alone or as a complement to morphological characterization (Martinelli et al., 2008). Among these, simple sequence repeats (SSR) or microsatellites are the markers of choice in many fruit species (Bouhadida et al., 2010; Martín et al., 2011; Öz et al., 2013). In the case of apples, a high number of SSR markers have been described (Gianfranceschi et al., 1998; Hokanson et al., 1998; Liebhard et al., 2002; Silfverberg-Dilworth et al., 2006). Apple molecular markers are the most appropriate for characterizing apple collections, more than morphological markers (Santesteban et al., 2009), although the latter are necessary to complete germplasm descriptions.

The aim of this study was to discriminate and identify 29 accessions of local apple cul- 
tivars collected in Southern Spain, as well as to study genetic relationships among them. Twelve SSRs were used for this purpose and their heterozygosity and discrimination power was evaluated. Additionally, 33 morphological traits were evaluated to complement molecular characterization.

\section{MATERIAL AND METHODS}

\section{Plant material}

Twenty-nine local apple genotypes belonging to 13 cultivar denominations were analyzed in this study (Table 1). Plant material (leaves and fruits) was collected from trees located in different orchards of Sevilla, Huelva, Córdoba, and Granada, which are provinces of Andalusia (Southern Spain) (Figure 1). Each tree was labeled with a unique identification number and GPS coordinates were recorded. Additionally, 2 traditional apple varieties ('De la riega' and 'Ernestina') from the SERIDA Germplasm Bank (Northen Spain), which were previously analyzed using the same microsatellite markers and for the same morphological traits (Dapena and Blázquez, 2009), were included.

Morphological characterization was performed in only 6 accessions because most trees in the study were old and in poor sanitary condition, and thus did not bear sound fruit. Twenty ripe fruits were collected from the trees following the guidelines of the International Union for the Protection on New Varieties of Plants (UPOV, 2005).

\section{Table 1. Information of local apple cultivars analyzed.}

\begin{tabular}{|c|c|c|c|c|}
\hline Variety & Identification No. & County & Province & Location \\
\hline 'Pero rosa' & $14-1$ & Olivares & Sevilla & La era 2 \\
\hline 'Pero rosa' & $14-2$ & Olivares & Sevilla & La era 2 \\
\hline 'Pero rosa' & $14-3$ & Olivares & Sevilla & La era 2 \\
\hline ‘Pero Rufino’ & $19-1$ & Galaroza & Huelva & La confesa 1 \\
\hline 'Pero Rufino' & $19-2$ & Galaroza & Huelva & La confesa 1 \\
\hline 'Pero Rufino' & $19-5^{2}$ & Galaroza & Huelva & La confesa 2 \\
\hline 'Pero Rufino' & $19-6$ & Galaroza & Huelva & La confesa 2 \\
\hline 'Pero Rufino' & $19-8$ & Galaroza & Huelva & Huerta Venecia \\
\hline 'Pero Ala blanca' & $24-1^{2}$ & Galaroza & Huelva & La confesa 2 \\
\hline 'Pero Ala blanca' & $24-2$ & Galaroza & Huelva & La confesa 2 \\
\hline 'Pero Joaquín chico' & $25-1$ & Galaroza & Huelva & La confesa 2 \\
\hline 'Pero Joaquín gordo' & $26-1^{2}$ & Galaroza & Huelva & La confesa 2 \\
\hline 'Castellana' & $27-1$ & Galaroza & Huelva & La confesa 2 \\
\hline 'Castellana' & $27-2$ & Galaroza & Huelva & La confesa 1 \\
\hline 'Castellana' & $27-3^{2}$ & Galaroza & Huelva & Los roblecillos \\
\hline 'Pero Minguela' & $31-1^{2}$ & Galaroza & Huelva & La confesa 1 \\
\hline 'Pero Minguela' & $31-2$ & Galaroza & Huelva & Los roblecillos \\
\hline 'Pero Minguela' & $31-3$ & Galaroza & Huelva & Los roblecillos \\
\hline 'Pero Minguela' & $31-4$ & Galaroza & Huelva & Los roblecillos \\
\hline 'Pedrera' & $43-1$ & Olivares & Sevilla & Huerta Macario 1 \\
\hline 'Pedrera' & $43-2$ & Olivares & Sevilla & Huerta Cachón \\
\hline 'Pedrera' & $43-3$ & Olivares & Sevilla & Huerta Cachón \\
\hline 'Maguillo' & $44-1$ & Olivares & Sevilla & Huerta Macario 1 \\
\hline 'Maguillo' & $44-3$ & Galaroza & Huelva & Los roblecillos \\
\hline 'Maguillo' & $44-4$ & Galaroza & Huelva & Huerta río Múrtigas \\
\hline "Pero Joaquín chico o grande"1 & $88-1$ & Galaroza & Huelva & Huerta Venecia \\
\hline 'Delio' & $90-2^{2}$ & Galaroza & Huelva & Huerta río Múrtigas \\
\hline 'Camueso de Carcabuey' & $102-1$ & Lucena & Córdoba & Vivero de Lucena de Córdoba \\
\hline 'Roja de la Alpujarra' & $103-1$ & Albuñuelas & Granada & \\
\hline
\end{tabular}

${ }^{1}$ The farmer was not able to determine the variety when the material was collected. ${ }^{2}$ Accesions characterized morphologically. 


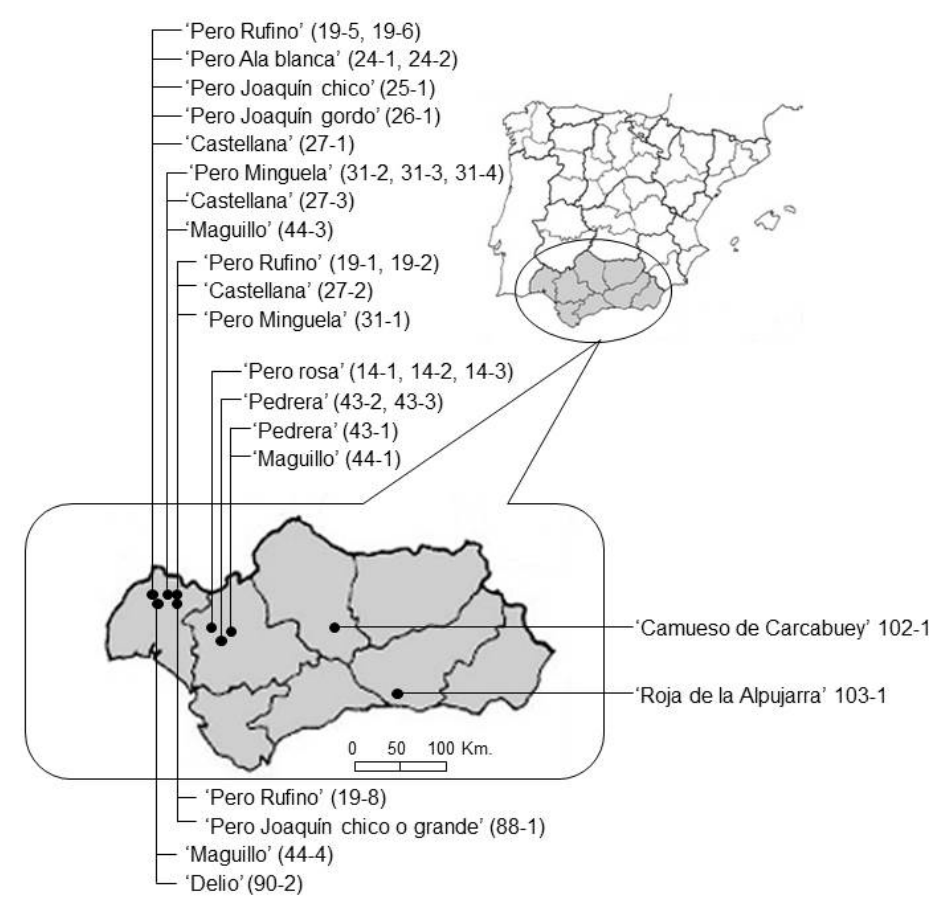

Figure 1. Sampling sites of the traditional apple cultivars analyzed in this study.

\section{DNA extraction and polymerase chain reaction (PCR) amplification}

Genomic DNA was isolated from adult leaves as described by Murray and Thompson (1980) with some modifications.

A set of 12 SSR loci developed for apple (Gianfranceschi et al., 1998, Hokanson et al., 1998, Liebhard et al., 2002, Silfverberg-Dilworth et al., 2006) were amplified by multiplex PCR as described by Lateur et al. (2013) by mixing 4 primer pairs per reaction. The primer sequences and the source of each SSR locus are described in Table 2. Forward primers were labeled with fluorescent dyes NED, 6-FAM, VIC, and PET (Applied Biosystems, Foster City, CA, USA). PCR reactions were carried out in a Thermal Cycler (Gene Amp PCR System 2700 ) in a final volume of $17.5 \mu \mathrm{L}$ containing $10 \mathrm{ng}$ genomic DNA, $2.0 \mathrm{mM} \mathrm{MgCl}$ (Invitrogen, Carlsbad, CA, USA), $0.2 \mathrm{mM}$ dNTPs (Applied Biosystems), 0.10-0.18 $\mu \mathrm{M}$ of each forward and reverse primer depending on the locus, and $5 \mathrm{U}$ Taq polymerase (Invitrogen). Cycling parameters were as follows: initial cycle of $94^{\circ} \mathrm{C}$ for $3 \mathrm{~min}, 35$ cycles at $94^{\circ} \mathrm{C}$ for 30 s, $50^{\circ} \mathrm{C}$ for $90 \mathrm{~s}$ (first 10 cycles began at $60^{\circ} \mathrm{C}$ and the temperature was reduced by $1^{\circ} \mathrm{C}$ per cycle until $50^{\circ} \mathrm{C}$ ), and $1 \mathrm{~min}$ at $72^{\circ} \mathrm{C}$, and a final cycle at $60^{\circ} \mathrm{C}$ for $30 \mathrm{~min}$.

To confirm amplification, $7 \mu \mathrm{L}$ PCR products were separated by electrophoresis on a $2 \%$ agarose gel and visualized using a UV transilluminator (BioDoc-it System, UVP, LLC, Upland, CA, USA). The amplified products were analyzed in a DNA capillary sequencer with ABI 3130 system (Applied Biosystems). The electrophoresis results were analyzed using the Gene Scan v 3.7 software. 
Table 2. SSR loci analyzed: name code, primer sequences (F: Forward; R: Reverse) and reference.

\begin{tabular}{|c|c|c|}
\hline SSR name & Primer sequence $\left(5^{\prime}-3^{\prime}\right)$ & Reference \\
\hline$\overline{\mathrm{CH} 01 \mathrm{~h} 01}$ & $\begin{array}{l}\text { F: GAAAGACTTGCAGTGGGAGC } \\
\text { R: GGAGTGGGTTTGAGAAGGTT }\end{array}$ & Gianfranceschi et al., 1998 \\
\hline $\mathrm{CH} 04 \mathrm{c} 07$ & $\begin{array}{l}\text { F: GGCCTTCCATGTCTCAGAAG } \\
\text { R: CCTCATGCCCTCCACTAACA }\end{array}$ & Liebhard et al., 2002 \\
\hline CH01h10 & $\begin{array}{l}\text { F: TGCAAAGATAGGTAGATATATGCCA } \\
\text { R: AGGAGGGATTGTTTGTGCAC }\end{array}$ & Gianfranceschi et al., 1998 \\
\hline Hi02c07 & $\begin{array}{l}\text { F: AGAGCTACGGGGATCCAAAT } \\
\text { R: GTTTAAGCATCCCGATTGAAAGG }\end{array}$ & Silfverberg-Dilworth et al., 2006 \\
\hline $\mathrm{CH} 01 \mathrm{f0} 2$ & $\begin{array}{l}\text { F: ACCACATTAGAGCAGTTGAGG } \\
\text { R: CTGGTTTGTTTTCCTCCAGC }\end{array}$ & Gianfranceschi et al., 1998 \\
\hline GD12 & $\begin{array}{l}\text { F: TTGAGGTGTTTCTCCCATTGGA } \\
\text { R: CTAACGAAGCCGCCATTTCTTT }\end{array}$ & Hokanson et al., 1998 \\
\hline $\mathrm{CH} 01 \mathrm{f03b}$ & $\begin{array}{l}\text { F: GAGAAGCAAATGCAAAACCC } \\
\text { R: CTCCCCGGCTCCTATTCTAC }\end{array}$ & Liebhard et al., 2002 \\
\hline GD147 & $\begin{array}{l}\text { F: TCCCGCCATTTCTCTGC } \\
\text { R: GTTTAAACCGCTGCTGCTGAAC }\end{array}$ & Hokanson et al., 1998 \\
\hline $\mathrm{CH} 04 \mathrm{e} 05$ & $\begin{array}{l}\text { F: AGGCTAACAGAAATGTGGTTTG } \\
\text { R: ATGGCTCCTATTGCCATCAT }\end{array}$ & Liebhard et al., 2002 \\
\hline $\mathrm{CH} 02 \mathrm{c} 11$ & $\begin{array}{l}\text { F: TGAAGGCAATCACTCTGTGC } \\
\text { R: TTCCGAGAATCCTCTTCGAC }\end{array}$ & Liebhard et al., 2002 \\
\hline CH02d08 & $\begin{array}{l}\text { F: TCCAAAATGGCGTACCTCTC } \\
\text { R: GCAGACACTCACTCACTATCTCTC }\end{array}$ & Liebhard et al., 2002 \\
\hline CH02c09 & $\begin{array}{l}\text { F: TTATGTACCAACTTTGCTAACCTC } \\
\text { R: AGAAGCAGCAGAGGAGGATG }\end{array}$ & Liebhard et al., 2002 \\
\hline
\end{tabular}

\section{Morphological characterization}

For morphological analysis, 33 characters were measured in fruit in 2010 (Table 3); 28 were selected from UPOV (2005) and 5 were previously described by Dapena and Blázquez (2009).

To measure these traits, 15 apples at full maturity from the original 20 -fruit sample were used because 5 were systematically discarded as outliers. Maturity was determined according to skin color based on information provided by the farmers.

Eleven quantitative traits were measured using a digital caliper with a sensitivity of $0.01 \mathrm{~mm}$, including height, diameter, ratio, width of stalk cavity, width of eye basin, depth of stalk cavity, depth of eye basin, length of stalk, thickness of stalk, length of sepal, and size of eye. Height to diameter ratio was calculated. The means and standard deviation (SD) were obtained for the quantitative characters studied.

Twenty-two qualitative parameters were measured by visualization: general shape, position of maximum diameter, fruit surrounding shape, regularity of fruit surrounding shape, ribbing, crowning at calix end, eye opening, bloom of skin, greasiness of skin, ground color, relative area of over color, hue of over color, intensity of over color, pattern of over color, area of russet around stalk attachment, area of russet on cheeks, area of russet around eye basin, number of lenticels, size of lenticels, lenticels shape, color of flesh, and aperture of locules.

In addition, cross-section and longitudinal section scanning were performed.

\section{Statistical analysis}

Different alleles detected for each SSR were indicated by the estimated size (bp). The presence or absence of all alleles in each accession were scored as 1 or 0 , respectively. To characterize the 12 loci, the following parameters were calculated: observed heterozygos- 
ity $\left(H_{\mathrm{O}}\right.$, calculated as the number of heterozygous genotypes divided by the total number of genotypes), expected heterozygosity

$$
\left(H e=1-\sum p i^{2}\right)
$$

(Equation 1)

where $p i$ is the frequency of $i^{\text {th }}$ allele (Nei, 1973) and power of discrimination

$$
\left(P D=1-\sum g i^{2}\right)
$$

where $g i$ is the frequency of $i^{\text {th }}$ genotype (Kloosterman et al., 1993).

To examine the genetic relationships among accessions, pair-wise similarity coefficients were calculated according to Dice (1945) and a dendrogram was constructed using unweighted pair group method with arithmetic mean algorithm. All analyses were carried out using the NTSYS-pc 2.0 package (Rohlf, 1997).

Principal component analysis was performed to select the most discriminant morpho-

\begin{tabular}{|c|c|c|}
\hline \multicolumn{2}{|c|}{ UPOV (2005) } & \multirow{2}{*}{$\begin{array}{l}\text { Dapena and Blázquez (2009) } \\
\text { Position of maximum diameter }\end{array}$} \\
\hline Height (mm) & Bloom of skin & \\
\hline Diameter (mm) & Greasiness of skin & Fruit surrounding shape \\
\hline Ratio height/diameter & Ground color & Regularity fruit surrounding shape \\
\hline General shape & Relative area of over color & Eye opening \\
\hline Ribbing & Hue of over color with bloom removed & Lenticels shape \\
\hline Crowning at calyx end & Intensity of over color & \\
\hline Size of eye & Pattern of over color & \\
\hline Length of sepal & Area of russet around stalk attachment & \\
\hline Depth of eye basin & Area of russet on cheeks & \\
\hline Width of eye basin & Area of russet around eye basin & \\
\hline Length of stalk (mm) & Number of lenticels & \\
\hline Thickness of stalk (mm) & Size of lenticels & \\
\hline Depth of stalk cavity & Color of flesh & \\
\hline Width of stalk cavity & Aperture of locules & \\
\hline
\end{tabular}
logical characters with the greatest variability (Pereira-Lorenzo et al., 2003).

\section{RESULTS}

\section{SSR polymorphism}

Table 4 summarizes the number of samples amplified per SSR locus as well as the total number of alleles, unique alleles, amplification range, and $H_{\mathrm{E}}, H_{\mathrm{O}}$, and DP values. The 31 samples analyzed (29 local accessions and 2 control cultivars) were not amplified for all loci. Only 20-29 samples, depending on the SSR locus, showed clear amplification products.

A total of 115 alleles were amplified from the 12 analyzed SSR loci used, ranging from 7 (CH01h01, CH01h10, and GD 12) to 13 alleles per locus $(\mathrm{CH} 02 \mathrm{c} 11)$ and therefore were highly polymorphic. A large number of alleles (41) were unique to some cultivars or even individuals. The locus with the highest number of unique alleles ( 6 alleles) detected was 
CH01f03b. The accession with the largest number of unique alleles was 'Maguillo' 44-3 with 9. The expected heterozygosity $\left(H_{\mathrm{E}}\right)$ varied from 0.74 for $\mathrm{CH} 01 \mathrm{~h} 10$ to 0.88 for $\mathrm{CH} 02 \mathrm{c} 11$, with an average of 0.82 . The observed heterozygosity $\left(H_{\mathrm{O}}\right)$ ranged from 0.45 for $\mathrm{CH} 01 \mathrm{~h} 01$ to 1.0 for $\mathrm{CH} 02 \mathrm{~d} 08$, with an average of 0.86 .

The CH02c11 microsatellite detected the largest number of alleles (13) and therefore was highly polymorphic, while the CH01h01, CH01h10, and GD12 loci were less polymorphic (with 7 alleles). Discrimination power ranged from 0.83-0.91.

Table 4. SSR amplification results regarding the number of samples amplified per SSR locus, the size range of alleles, the number of alleles, the number of unique alleles, the observed heterozygosity $\left(H_{\mathrm{O}}\right)$, the expected heterozygosity $\left(H_{\mathrm{E}}\right)$ and the discrimination power (DP).

\begin{tabular}{|c|c|c|c|c|c|c|c|}
\hline SSR Locus & No. of samples/ssp & Size range (bp) & No. of alleles & No. of unique alleles & $H_{\mathrm{o}}$ & $H_{\mathrm{E}}$ & DP \\
\hline $\mathrm{CH} 01 \mathrm{~h} 01$ & 20 & $109-136$ & 7 & 3 & 0.45 & 0.77 & 0.83 \\
\hline $\mathrm{CH} 04 \mathrm{c} 07$ & 23 & $93-127$ & 10 & 4 & 0.70 & 0.84 & 0.85 \\
\hline CH01h10 & 27 & $105-121$ & 7 & 3 & 0.63 & 0.74 & 0.83 \\
\hline $\mathrm{Hi02c07}$ & 27 & $68-156$ & 9 & 5 & 0.48 & 0.78 & 0.85 \\
\hline GD 12 & 20 & $133-153$ & 7 & 2 & 0.70 & 0.80 & 0.88 \\
\hline $\mathrm{CH} 01 \mathrm{f0} 2$ & 21 & $167-213$ & 11 & 5 & 0.57 & 0.86 & 0.88 \\
\hline CH01f03b & 21 & $132-189$ & 11 & 6 & 0.76 & 0.81 & 0.87 \\
\hline GD 147 & 23 & $136-179$ & 9 & 3 & 0.65 & 0.82 & 0.87 \\
\hline $\mathrm{CH} 04 \mathrm{e} 05$ & 28 & $156-226$ & 10 & 2 & 0.89 & 0.80 & 0.88 \\
\hline $\mathrm{CH} 02 \mathrm{c} 11$ & 29 & $205-239$ & 13 & 5 & 0.90 & 0.88 & 0.91 \\
\hline $\mathrm{CH} 02 \mathrm{~d} 08$ & 29 & $232-256$ & 11 & 4 & 1.00 & 0.86 & 0.87 \\
\hline $\mathrm{CH} 02 \mathrm{c} 09$ & 29 & $209-254$ & 10 & 3 & 0.97 & 0.86 & 0.87 \\
\hline
\end{tabular}

\section{Accession fingerprinting}

Using all 12 SSR loci, 18 different amplification patterns were detected from the 29 accessions analyzed.

The 3 'Maguillo' accessions studied (44-1, 44-3, and 44-4) showed very different amplification patterns in all loci analyzed. For 'Pero Minguela' cultivar samples, allelic profiles for 31-1 with respect to 31-2 and 31-3 accessions were the same in all loci, but 1 was different (GD 147). However, sample 31-4 showed different amplification patterns in 7 loci. Similar results were observed for 'Castellana' accessions, for which individuals 27-1 and 27-2 shared the same genetic profiles, but a slight difference was observed for sample 27-3 at locus CH01f02.

\section{Phylogenetic relationships}

To examine the genetic relationships among apple cultivars, a dendrogram was performed using unweighted pair group method with arithmetic mean cluster analysis based on the Dice similarity coefficient (Figure 2). Apple genotypes were clustered into 4 main groups. The first group included 'De la riega', 'Pero Minguela' (31-1, 31-2, 31-3, and 31-4), 'Roja de la Alpujarra', 'Pero Rosa' (14-1, 14-2, and 14-3), 'Delio', 'Ernestina', 'Pero Joaquín chico o grande', and 'Castellana' (27-1, 27-2, and 27-3). The second group included 'Pero Rufino' (19-1, 19-2, 19-5, 19-6, and 19-8), 'Maguillo' (44-1 and 44-4), 'Pero ala blanca' (24-1 and 24-2), 'Pero Joaquin gordo', and 'Camueso de Carcabuey'. The third group only included the 'Maguillo' sample 44-3 and the fourth included the 3 'Pedrera' samples (43-1, 43-2, and 43-3).

Dice's genetic similarity among the samples analyzed ranged from $0.15-0.67$, when different varietal denominations were considered, or up to 0.99 when considering possible 
homonyms or clonal variation cases.

Genotype 44-1, thought to be 'Maguillo', largely differed from the other 2 'Maguillo' samples (44-4 and 44-3). Similarly, 'Pero Minguela' genotype 31-4, although in the same main cluster, was located far from the other samples of the same name, while for individual 31-1, the distance to the samples 31-2 and 31-3 was much smaller. Similarly, the distance among 'Castellana' tree 27-3 and the other 2 samples of 'Castellana' (27-1 and 27-2) was very small.

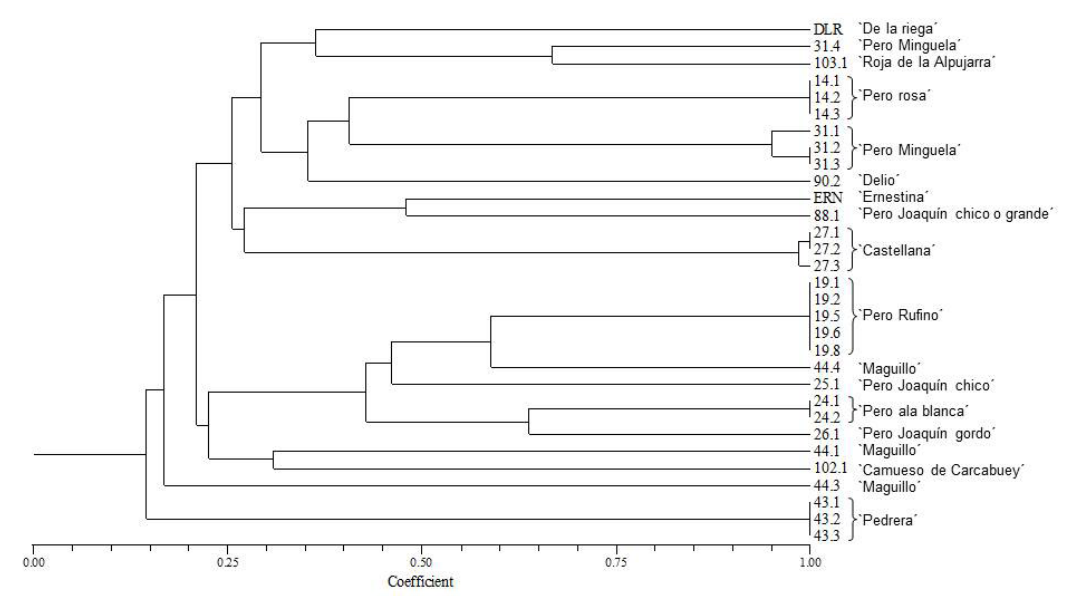

Figure 2. Dendrogram of the 31 apple accessions studies obtained by unweighted pair group method with arithmetic mean cluster analysis using Dice coefficient after amplification with 12 SSR loci.

\section{Morphological characterization}

The 11 more relevant quantitative characters measured in the fruit samples are summarized in Table 5. Fruit height varied from $39.25 \mathrm{~mm}$ for 'Castellana' to $66.80 \mathrm{~mm}$ for 'Pero Gordo' and the diameter ranged from $49.37 \mathrm{~mm}$ ('Castellana') to $74.45 \mathrm{~mm}$ ('Pero Gordo'), while eye size was similar for all varieties, ranging from $3.40-4.43 \mathrm{~mm}$.

The more important qualitative characters are shown in Tables 6 and 7. The fruit shape was predominantly globose ('Pero Rufino', 'Pero Gordo', 'Pero Ala blanca', and 'Pero Minguela'), although other shapes were observed such as ellipsoid ('Castellana') and obloid ('Delio'). The ground color observed was green ('Pero Rufino', 'Pero Ala blanca', and 'Pero Minguela') and yellow green ('Pero Gordo', 'Castellana', and 'Delio'). Only 2 varieties had hue of over color: 'Castellana' was red and 'Pero Ala blanca' was orange-red.

The morphological characteristics studied with greater morphological diversity were the quantitative characters fruit height and diameter. In addition, morphological diversity was observed based on the qualitative character shape, which showed 3 types of shapes of the 7 defined by UPOV.

Using principal component analysis for the morphological characters studied, 3 of the first 5 principal components (PC) accounted for $85.87 \%$ of the total variance (Table 8 ).

The most important characters in each PC were as follows. PC1: relative area of over color, pattern of over color, hue of over color, size of over color, and intensity of over color. PC2: ratio height/diameter. PC3: ground color and length of stalk. PC4: bloom of skin, grassiness of skin, width of eye basin, and general shape. PC5: length of sepal and thickness of stalk. 


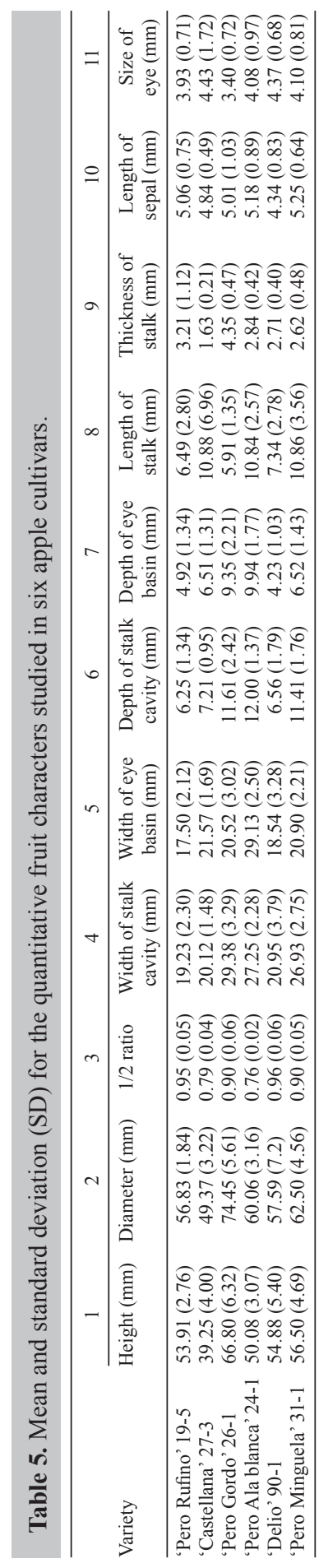




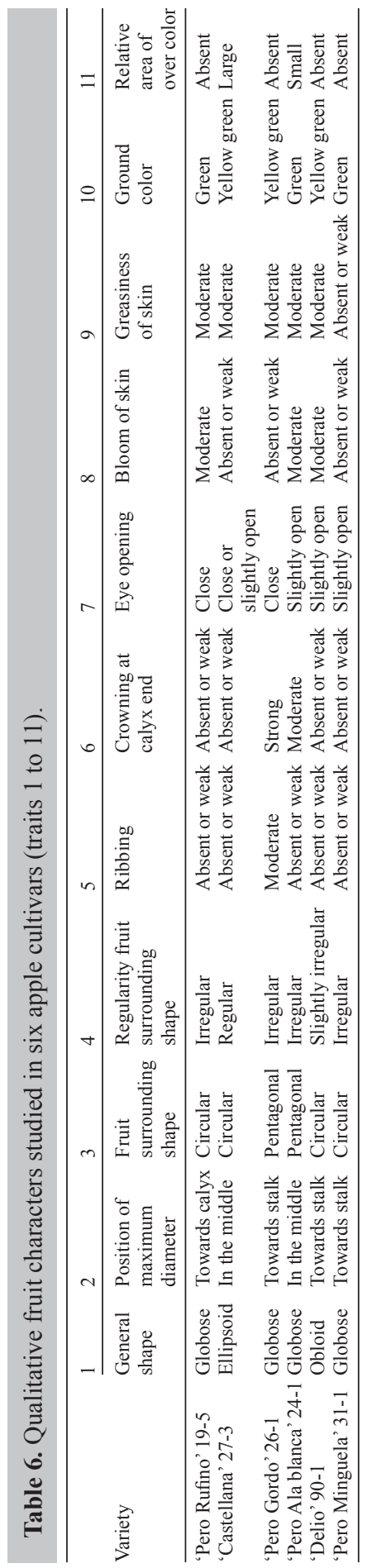




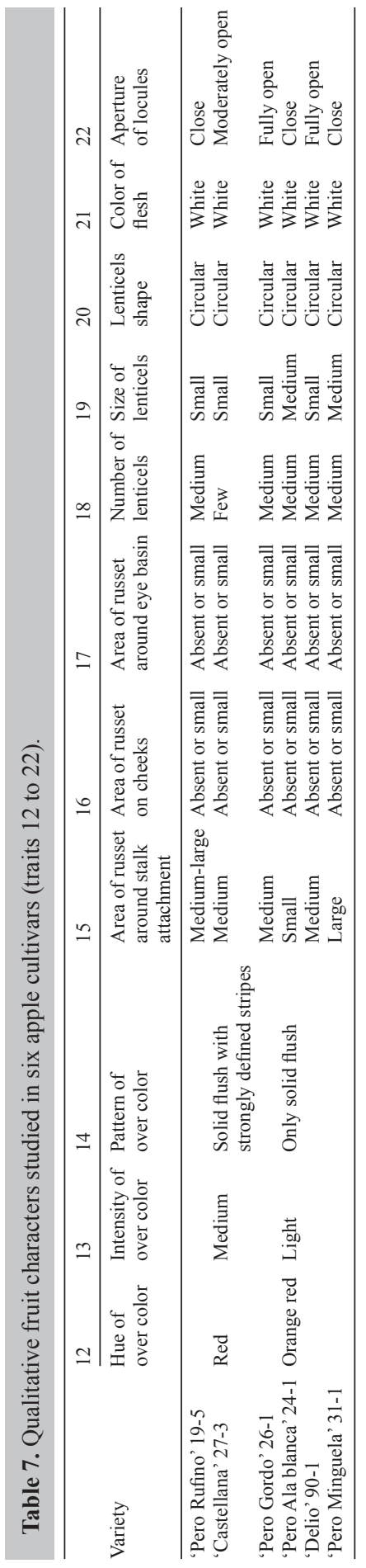


Table 8. Eigen values, and variance, accumulated variance for the first five principal components.

\begin{tabular}{lccc}
\hline PC & Eigen value & Variance & Accumulated variance \\
\hline 1 & 8.94 & 42.55 & 42.55 \\
2 & 6.06 & 28.84 & 71.39 \\
3 & 3.04 & 14.48 & 85.87 \\
4 & 1.87 & 8.89 & 94.76 \\
5 & 1.10 & 5.24 & 100 \\
\hline
\end{tabular}

\section{DISCUSSION}

In this study, SSR markers and morphological traits were used to evaluate 29 samples from old traditional apple cultivars collected in Southern Spain. None of these cultivars are currently preserved in any of the Spanish germplasm banks.

The results obtained from molecular characterization studies indicated that the level of polymorphism is similar to values reported in other studies for local apple cultivars in Spain (Pereira-Lorenzo et al., 2008; Urrestarazu et al., 2012), although the number of samples in our study was smaller.

Variability parameters calculated for each SSR locus employed (Table 4) differed slightly from those indicated by the authors that originally developed the SSRs. For CH04c07, CH01f03b, CH04e05, CH02c11, CH02d08, CH02c09, CH01h10, CH01f02, and GD12 loci previously described by Liebhard et al. (2002), Gianfranceschi et al. (1998), and Hokanson et al. (1998), we found higher values of expected heterozygosity.

The number of unique alleles observed was very high, reinforcing that high genetic diversity exists within the sample analyzed. This is likely due to the different origin sources of traditional apple varieties in Western Andalusia; in fact, it is known by farmers that some of these cultivars were introduced in the area from various parts of Northern Spain at the beginning of the 20th century.

Some samples failed to amplify some loci (Table 4). This lack of amplification may be related to the presence of null alleles in the flanking regions (Hokanson et al., 1998; Liebhard et al., 2002; Silfverberg-Dilworth et al., 2006), although it also may be because of poor DNA quality. Both explanations are possible given the high genetic diversity in the samples analyzed as evidenced by SSR results (more possibilities of mutations or changes in flanking regions), as well as the poor DNA quality that may be related to a subset of old trees that were in a highly bad sanitary status.

Our results showed 18 different amplification patterns for the 29 samples analyzed. Because there were only 13 cultivar denominations, clonal variation among cultivars or even homonyms may exist, i.e., same name for different cultivars. Homonyms are very common in traditional plant material and have been detected by microsatellites in several fruit species such as almond (Gouta et al., 2010), grape (Fernández-González et al., 2007; Boz et al., 2011), pear (Brini et al., 2008), olive (Isik et al., 2011), and chestnut (Gobbin et al., 2007). Different allelic profiles have been detected among samples of 'Maguillo', 'Pero Minguela', and 'Castellana' cultivars. The 'Maguillo' name has been traditionally used to refer a rootstock with sexual propagation through seeds which would explain why the 3 samples were very genetically different. For 'Pero Minguela', sample 31-1, samples 31-2 and 31-3 differed in only 1 of 12 loci, and thus, may be a possible case of intracultivar variation as suggested for other fruit species (Noormohammadi et al., 2009), while sample 31-4, differing in 7 loci profiles, was 
more likely a case of homonymous denomination. Similarly, 'Castellana' sample 27-3 showed a slight allelic difference at 1 locus, suggesting clonal variation.

The dendrogram generated by unweighted pair group method with arithmetic mean cluster analysis (Figure 2) confirmed these observations. All 3 'Maguillo' samples fell largely apart in the dendrogram, which may be explained by a seedling origin of this denomination or even the use of wild apple relatives as rootstocks under the same name. Similarly, 'Pero Minguela' sample 31-4 is located in a different sub-cluster and distant to the other 3 samples of the same cultivar, supporting homonymy. In contrast, sample 'Pero Minguela' 31-1 is within the same sub-cluster and was close to the other 2 samples, suggesting clonal variation affecting a specific SSR locus length. The same applies for 'Castellana' tree 27-3, for which the distance to the other samples of 'Castellana' (27-1 and 27-2) was nearly negligible.

The dendrogram also showed that the 2 varieties from the SERIDA Germplasm Bank were included in the first group along with 'Pero Minguela', 'Roja de la Alpujarra', 'Pero Rosa', 'Delio', 'Pero Joaquín chico o grande', and 'Castellana', suggesting that varieties in this cluster were from the North of Spain or that these accessions were hybridized with varieties from Northern Spain.

Morphological characterization was used to describe the different accessions. Using 3 of the first 5 principal components, we found a higher percentage of total variance compared to values found in other studies (Pérez et al., 1993; Pereira-Lorenzo et al., 2003), although the number of accessions in this study was lower.

As conclusions, 29 accessions belonging to 13 traditional apple cultivars collected in Southern Spain and presumably not present in any of the national germplasm banks were analyzed using 12 SSR markers. The microsatellites used allowed for molecular discrimination of 18 different genotypes, revealing the existence of several homonyms among the 'Maguillo' and 'Pero Minguela' accessions. Although the number of accessions analyzed was limited, the genetic diversity of the samples studied was very high as revealed by the large number of alleles, unique alleles, and expected heterozygosity values, compared to previous studies. A wide range of variation was also found among morphological traits, primarily fruit height, diameter, and shape. The high diversity of the traditional cultivars analyzed suggests a diverse origin of apples grown in Andalusia and highlights the importance of preserving this endangered plant material for future use in breeding programs.

\section{ACKNOWLEDGMENTS}

Research supported by the Spanish Ministry of Science and Innovation and FEDER (\#RF-2007-00027-C06-05), and co-financed by the INIA. The authors fully acknowledge the farmers who provided plant material and all the colleagues who worked in plant surveys, Araceli Sánchez, $\mathrm{M}^{\mathrm{a}}$ Rocío Jiménez, Laura Casanova, and Ana $\mathrm{M}^{\mathrm{a}}$ Morales.

\section{REFERENCES}

Barranco D and Rallo L (2000). Olive cultivars in Spain. Horttechnology 10: 107-110.

Bouhadida M, Moreno MA, Gonzalo MJ, Alonso JM, et al. (2010). Genetic variability of introduced and local Spanish peach cultivars determined by SSR markers. Tree Genet. Genomes 7: 257-270.

Boz Y, Bakir M, Celikkol BP, Kazan K, et al. (2011). Genetic characterization of grape (Vitis vinifera L.) germplasm from Southeast Anatolia by SSR markers. Vitis 50: 99-106. 
Brini W, Mars M and Hormaza JI (2008). Genetic diversity in local Tunisian pears (Pyrus communis L.) studied with SSR markers. Sci. Hortic. 115: 337-341.

Cantini C, Cimato A and Sani G (1999). Morphological evaluation of olive germplasm present in Tuscany region. Euphytica 109: 173-181.

Dapena E and Blázquez M (2009). Descripción de las variedades de manzana de la D.O.P. Sidra de Asturias. SERIDA, Asturias.

Dice LR (1945). Measures of the amount of ecologic association between species. Ecology 26: 297-302.

Fernández-González M, Mena A, Izquierdo P and Martinez J (2007). Genetic characterization of grapevine (Vitis vinifera L.) cultivars from Castilla La Mancha (Spain) using microsatellite markers. Vitis 46: 126-130.

Gianfranceschi L, Seglias N, Tarchini R, Komjanc M, et al. (1998). Simple sequence repeats for the genetic analysis of apple. Theor. Appl. Genet. 96: 1069-1076.

Gobbin D, Hohl L, Conza L, Jermini M, et al. (2007). Microsatellite-based characterization of the Castanea sativa cultivar heritage of southern Switzerland. Genome 50: 1089-1103.

Gouta H, Ksia E, Buhner T, Moreno MA, et al. (2010). Assessment of genetic diversity and relatedness among Tunisian almond germplasm using SSR markers. Hereditas 147: 283-293.

Hend BT, Ghada B, Sana BM, Mohamed M, et al. (2009). Genetic relatedness among Tunisian plum cultivars by random amplified polymorphic DNA analysis and evaluation of phenotypic characters. Sci. Hortic. 121: 440-446.

Hokanson SC, Szewc-McFadden AK, Lamboy WF and McFerson JR (1998). Microsatellite (SSR) markers reveal genetic identities, genetic diversity and relationships in a Malus $x$ domestica Borkh. core subset collection. Theor. Appl. Genet. 97: 671-683.

Isik N, Doganlar S and Frary A (2011). Genetic diversity of Turkish olive varieties assessed by simple sequence repeat and sequence-related amplified polymorphism markers. Crop Sci. 51: 1646-1654.

Kloosterman AD, Budowle B and Daselaar M (1993). PCR-amplification and detection of the human DIS80 VNTR locus. Amplification conditions, population genetics and application in forensic analysis. Int. J. Legal Med. 105: 257-264.

Lateur M, Ordidge M, Engels J and Lipman E (2013). Report of a Working Group on Malus/Pyrus. Fourth Meeting, March 7-9, 2012, Weggis, Switzerland. Biodiversity International, Rome, Italy.

Liebhard R, Gianfranceschi L, Koller B, Ryder CD, et al. (2002). Development and characterization of 140 new microsatellites in apple (Malus $x$ domestica Borkh.). Mol. Breed. 10: 217-241.

Martín C, Herrero M and Hormaza JI (2011). Molecular characterization of apricot germplasm from an old stone collection. PLoS One 6: e23979.

Martinelli F, Busconi M, Camangi F, Fogher C, et al. (2008). Ancient Pomoideae (Malus domestica Borkh and Pyrus communis L.) cultivars in “Appenino Toscano" (Tuscany, Italy): molecular (SSR) and morphological characterization. Caryologia 61: 320-331.

Murray MG and Thompson WF (1980). Rapid isolation of high molecular weight DNA. Nucleic Acids Res. 8: 4321-4325.

Nei M (1973). Analysis of gene Diversity in subdivided populations. Proc. Natl. Acad. Sci. USA 70: 3321-3323.

Noormohammadi Z, Hosseini-Mazinani M, Trujillo I and Belaj A (2009). Study of intracultivar variation among main Iranian olive cultivars using SSR markers. Acta Biol. Szeged. 53: 27-32.

Öz MH, Vurgun H, Bakir M, Büyük I, et al. (2013). Molecular analysis of East Anatolian traditional plum and cherry accessions using SSR markers. Genet. Mol. Res. 12: 5310-5320.

Pereira-Lorenzo S, Ramos-Cabrer AM, Ascasíbar-Errasti J and Piñeiro-Andión J (2003). Analysis of apple germplasm in NorthWestern Spain. J. Am. Soc. Hortic. Sci. 128: 67-84.

Pereira-Lorenzo S, Ramos-Cabrer AM and Díaz-Hernández MB (2007). Evaluation of genetic identity and variation of local apple cultivars (Malus x domestica) from Spain using microsatellite markers. Genet. Resour. Crop Evol. 54: 405-429.

Pereira-Lorenzo S, Ramos-Cabrer AM, González-Díaz AJ and Díaz-Hernández MB (2008). Genetic assessment of local apple cultivars from La Palma, Spain, using simple sequence repeats (SSRs). Sci. Hortic. 117: 160-166.

Pérez S, Montes S and Mejía C (1993). Analysis of peach germplasm in Mexico. J. Am. Soc. Hortic. Sci. 118: 519-524.

Rao R, Bencivenni M, La Mura M, Araujo-Burgos T, et al. (2010). Molecular characterization of Vesuvian apricot cultivars: implications for the certification and authentication of protected plant material. J. Hortic. Sci. Biotechnol. 85: 42-47.

Rohlf FJ (1997). NTSYS-PC: numerical taxonomy and multivariate analysis system. Exeter software, Stony Brook, New York.

Rotondi A, Magli M, Ricciolini C and Baldoni L (2003). Morphological and molecular analyses for the characterization of a group of Italian olive cultivars. Euphytica 132: 129-137.

Santesteban LG, Miranda C and Royo BJ (2009). Assessment of the genetic and phenotypic diversity maintained in apple core collections constructed by using either agro-morphologic or molecular marker data. Span. J. Agric. Res. 7: $572-584$. 
Silfverberg-Dilworth E, Matasci CL, Van de Weg WE, Van Kaauwen MPW, et al. (2006). Microsatellite markers spanning the apple (Malus $x$ domestica Borkh.) genome. Tree Genet. Genomes 2: 202-224.

UPOV (2005). Guidelines for the conduct of tests for distinctness, homogeneity and stability (Apple). International Union Protection New Varieties Plants.

Urrestarazu J, Miranda C, Santesteban LG and Royo JB (2012). Genetic diversity and structure of local apple cultivars from Northeastern Spain assessed by microsatellite markers. Tree Genet. Genomes 8: 1163-1180. 